DOI: http://dx.doi.org/10.4322/apa.2015.012

\title{
EPILITHIC FRESHWATER DIATOMS FROM ELEPHANT ISLAND, SOUTH SHETLANDS, ANTARCTICA
}

\section{Juliana Ferreira da Silva ${ }^{1 *}$, Maria Angélica Oliveira ${ }^{1}$, Antônio Batista Pereira ${ }^{2}$, Clarissa Kappel Pereira ${ }^{2} \&$ Cristiane Barbosa D'Oliveira ${ }^{2}$}

\begin{abstract}
'Universidade Federal de Santa Maria, Avenida Antônio Trilha, 1847, CEP 97300-000, São Gabriel, RS, Brazil Universidade Federal do Pampa, Avenida Roraima, 1000, CEP 97105-900, Camobi Santa Maria, RS, Brazil
\end{abstract}

$$
\text { *email: jusferre@yahoo.com.br }
$$

\begin{abstract}
Epilithic diatom species from six sampling stations on Elephant Island, South Shetlands, Antarctica, are presented in this paper. Samples were taken in the austral summer of 2011-2012 from submerged stones in two lakes and four streams. Species identification was carried out by light and scanning electron microscopy. A total of 19 species in 12 genera were determined. The most representative genera considering number of species were Gomphonema Ehr. and Pinnularia Ehr. Compared to species inventories on other islands of the South Shetlands archipelago, species richness on Elephant Island is low, and further investigation is needed in order to determine the causes, whether environmental or result of biotic interactions.
\end{abstract}

Keywords: Periphyton, Bacillariophyceae, Maritime Antarctica

\section{Introduction}

One of the main archipelagos in the South Atlantic Ocean are the South Shetlands, a group of 11 mountainous islands, located $160 \mathrm{~km}$ North of the Antarctic Peninsula (Van de Vijver et al., 2009). Elephant Island is the northernmost of the islands, located at $885 \mathrm{~km}$ from Cape Horn, Chile. Studies carried out on the diversity of freshwater periphytic diatoms (Bacillariophyceae) in Antarctic freshwater habitats are scarce, even though a recent interest in this flora has arisen (Spaulding et al., 2010). Accounts of diatom floras on Elephant Island are limited to planktonic marine species (Villafañe et al., 1993, 1995), with no published articles on diversity of epilithic communities of lakes and temporary streams on the island. The periphytic community is composed of algae and other microorganisms attached to or associated with different substrates. Algae are the main producers in these communities and diatoms are of great quantitative importance. In locations of melting ice, the epilithic type of periphyton (developing on submerged stones and rocks) is the most abundant. Since species composition in the communities is determined by hydrological conditions, trophic state and type of substrate available for colonization (chemical composition, roughness, etc.) as well as ecological preferences of the containing species (Charles \& Charles, 2003), information on diversity is crucial for a better understanding of environment dynamics. The species diversity of diatoms of inland habitats in Antarctica is low compared to both temperate and Arctic regions, due, in part, to physical isolation of the continent. The freshwater diatom flora of the Antarctic Islands is unique with several endemic species (Van de Vijver et al., 2001; 2002; 2004) and some species which are restricted to only one island or group of islands, whereas others occur more widely in the region (Van de Vijver et al., 2008). Also, diatoms are one of the most abundant groups of freshwater algae in terrestrial subantarctic habitats (Jones,1996).

Due to the great ecological importance of periphytic diatoms in these habitats, as well as the key role of microalgae in the characterization of freshwater habitats, this study aimed at describing the diatom flora in five shallow freshwater systems of Elephant Island. 


\section{Materials and Methods}

Samples were taken in the austral summer of 20112012 during the $30^{\circ}$ Brazilian Antarctic Operation (Operantar XXX). Six different freshwater systems were sampled on Elephant Island: station 1 (61'13'58.6”S and

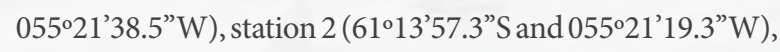
station $4\left(61^{\circ} 13^{\prime} 19.0^{\prime \prime} \mathrm{S}\right.$ and $\left.055^{\circ} 21^{\prime} 40.2^{\prime \prime} \mathrm{W}\right)$, and station 5 $\left(61^{\circ} 13^{\prime} 21,5^{\prime \prime} \mathrm{S}\right.$ and $\left.055^{\circ} 21^{\prime} 42,4^{\prime \prime} \mathrm{W}\right)$ were melting ice streams (station 1 ran across a penguin breeding ground); station 3 (61 ${ }^{\circ} 13^{\prime} 55.4^{\prime \prime} S$ and $055^{\circ} 21^{\prime} 03.0^{\prime \prime} \mathrm{W}$ ) was located on Endurance Lake and station 6 (61 $11^{\prime} 18.5^{\prime \prime} S$ and 055²1'48,0"W) on Skua Lake.

Epilithic diatom samples were obtained from stones scrubbed with a toothbrush and rinsed with distilled water. Each sample was bottled, fixed with $4 \%$ formaldehyde and transported to the Phycology Lab at Universidade Federal de Santa Maria at the end of the expedition. Samples were processed an cleaned by boiling with hydrogen peroxide
$\left(\mathrm{H}_{2} \mathrm{O}_{2}\right)$ 1:1 solution for three hours, in order to remove any organic matter from the diatom frustules and organic content from the periphytic matrix. Permanent slides were mounted in Styrax (1,6 RI) for light microscopy analyses, which were carried out using a Leica DM750 light microscope. For scanning electron microscopy the oxidized samples were mounted on aluminum stubs after air-drying. The stubs were sputter coated with $50 \mathrm{~nm}$ of Au and studied in a JEOL SEM at $10 \mathrm{kV}$.

Species identification was carried out by population analysis, with measurements of length (C), width (L) and density of striae in $10 \mu \mathrm{m}$ taken from at least 25 individuals of each species. All recorded individuals were photographed.

\section{Results}

An average of 400 individuals was observed on each glass slide (each representing one sampling site). A total of 19 species in 12 genera were determined, listed in Table 1 . The

Table 1. list of genera and species of epilithic diatoms recorded in six sampling stations on Elephant Island, South Shetlands, in the austral summer of $2011-2012$.

\begin{tabular}{|c|c|}
\hline Genus & Species \\
\hline Achnanthidium & Achnanthidium delicatulum Kützing \\
\hline Amphora & Amphora sp \\
\hline Chamaepinnularia & Chamaepinnularia krookiformis (Krammer) Lange-Bertalot \& Krammer \\
\hline \multirow[t]{2}{*}{ Fragillaria } & Fragillaria capucina Desmazieres \\
\hline & Fragillaria capucina var voucheriae (Kütz) Lange-Bertalot \\
\hline Geissleria & Geissleria subantarctica Van de Vijver \& Le Cohu \\
\hline \multirow[t]{3}{*}{ Gomphonema } & Gomphonema parvulum (Kütz) Kütz \\
\hline & Gomphonema sp1 \\
\hline & Gomphonema sp2 \\
\hline Luticola & Luticola multicopsis (Van Heurck) D.G. Mann \\
\hline Mayamaea & Mayamaea atomus (Kützing) Lange-Bertalot \\
\hline Navicula & Navicula gregaria Cholnoky \\
\hline \multirow[t]{2}{*}{ Nitzschia } & Nitzschia gracilis Hantzsch \\
\hline & Nitzschia homburguiensis Lange-Bertalot \\
\hline \multirow[t]{4}{*}{ Pinnularia } & Pinnularia microstauron (Ehr.) Cleve \\
\hline & Pinnullaria sp1 \\
\hline & Pinnularia sp2 \\
\hline & Pinnularia sp3 \\
\hline Psammonthidium & Psammonthidium papilio (D.E.Kellogg) Van de Vijver \& Kopalová \\
\hline
\end{tabular}


most representative genera considering number of species were Gomphonema Ehr. and Pinnularia Ehr.

\section{Discussion}

Despite the significant progress made in the past 15 years with respect to the diversity of non-marine diatom flora from the Antarctic islands (Van de Vijver et al., 2013), species inventories and community studies are still scarce, with the majority of the studies concentrating in taxonomic reviews of genera and families. Of the few existing references for the South Shetlands, Kawecka et al., (1998) observed 78 diatoms species in shallow water bodies in the vicinity of $\mathrm{H}$. Arctowski Polish Antarctic Station, on King George Island. Also on the same island, Lobo et al., (1998) identified 25 epilithic diatom species in nine genera from lakes around the Brazilian Antarctic Station Comandante Ferraz, collected in 1989 and 1990. On James Ross Island, situated off the southeast side and near the northeastern extremity of the Antarctic Peninsula, Kopalová et al., (2012) listed 69 benthic diatom species in 26 genera from 34 samples collected between 2004 and 2009.

Despite the still limited number of studies, it is possible to say that the non-marine diatom flora of the Antarctic islands is currently under revision, with the description of several new species, previously believed to be cosmopolitan, but recently proven to be typical of Antarctic habitats (Van de
Vijver et al., 2008). The most species rich genus on Elephant Island was Pinnularia Ehr., a common and diverse taxon in Antarctic freshwaters (Kellogg \& Kellogg, 2002). Several new species of this genus have recently been described (Van de Vijver et al., 2002; Van de Vijver et al., 2008) in Antarctica.

\section{Conclusion}

When compared to numbers from other Antarctic islands, the species richness registered on Elephant Island is low, and further investigation is needed in order to determine the causes, whether environmental or resulting of biotic interactions.

\section{Acknowledgements}

This work was supported by the National Institute of Science and Technology Antarctic Environmental Research (INCT-APA) that receives scientific and financial support from the National Council for Research and Development (CNPq process: $n^{\circ}$ 574018/2008-5) and Carlos Chagas Research Support Foundation of the State of Rio de Janeiro (FAPERJ n E-16/170.023/2008). The authors also acknowledge the support of the Brazilian Ministries of Science, Technology and Innovation (MCTI), of Environment (MMA) and Inter-Ministry Commission for Sea Resources (CIRM).

\section{References}

Jones, V. J. (1996) the diversity, distribution and ecology of diatoms from Antarctic inland waters. Biodiversity and Conservation, 5(11), 1433-1449. http://dx.doi.org/10.1007/BF00051986

Kawecka, B., Olech, M., \& Nowogrodzka-Zago, M. (1998). Diatom communities in small water bodies at H. Arctowski Polish Antarctic Station (King George Island, South Shetland Islands, Antarctica. Polar Biology, 19(3), 183-192. http://dx.doi. org/10.1007/s003000050233

Kellogg, T. B., \& Kellogg, D. E. (2002). Non-marine and littoral diatoms from Antarctic and sub-Antarctic locations: distribution and updated taxonomy. Diatom Monographs, 1, 1-795.

Kopalová, K., Veselá, J., Elster, J., Nedbalová1, L., Komárek, J., \& Van de Vijver, B. (2012). Benthic diatoms (Bacillariophyta) from seepages and streams on James Ross Island (NW Weddell Sea, Antarctica). Plant Ecology and Evolution, 145(2), 190-208. http://dx.doi.org/10.5091/plecevo.2012.639

Lobo, E. A., Callegaro, V. L. M., \& Oliveira, M. A. O. (1998). Diatoms from two lake sin Penninsula Keller, King George Island, Antarctica. Caderno de Pesquisa, Série Botânica, 10(1-2), 3-25.

Potapova, M., \& Charles, D. F. (2003) Distribution of benthic diatoms in U.S. rivers in relation to conductivity and ionic composition. Freshwater Biology, 48, 1311-1328. http://dx.doi.org/10.1046/j.1365-2427.2003.01080.x 
Spaulding, S. A., Vijver, B. V., Hodgson, D. A., Mcknight, D. M., Verleyen, E., \& Stanish, L. (2010). Diatoms as indicators of environmental change in Antarctic and subantarctic freshwaters. In J. P. Smol \& E. F. Stoermer. The diatoms: applications for the environmental and earth sciences (2nd ed.). Cambridge: Cambridge University Press. 667 p.

Van de Vijver, B., Ledeganck, P., \& Beyens, L. (2001) Habitat preference in freshwater diatom communities from sub-Antarctic fles Kerguelen. Antarctic Science. 13, 28-36.

Van de Vijver, B., Frenot, Y., \& Beyens, L. (2002) Freshwater diatoms from lle de la Possession (Crozet archipelago, Subantarctica). Bibliotheca Diatomologica, 46, 1412

Van de Vijver, B., Beyens, L., Vincke, S., \& Gremmen, N. J. M. (2004). Moss-inhabiting diatom communities from Heard island, sub-Antarctic. Polar Biology, 27(9), 532-543. http://dx.doi.org/10.1017/S0954102001000050

Van de Vijver, B., Kelly, M., Blanco, S., Jarlman, A., \& Ector, L. (2008). The unmasking of a sub-antarctic endemic: Psammothidium abundans (Manguin) Bukhtiyarova et Round in european rivers. Diatom Research. 23(I), 233-242. http://dx.doi.org/10.10 80/0269249X.2008.9705749

Van de Vijver, B., Agius, J. T., Gibson, J. A. E., \& Quesada, A. (2009). An unusual spine-bearing pinnularia species from the antarctic livingston island (south shetland islands). Diatom Research, 24(2), 431-444. http://dx.doi.org/10.1080/026924 9X.2009.9705812

Van de Vijver, B., Cocquyt, C., Haan, M., Kopalová, K., \& Zidarova, R. (2013). The genus Surirella (Bacillariophyta) in the subAntarctic and maritime Antarctic region. Diatom Research, 28(1), 92-108. http://dx.doi.org/10.1080/0269249X.2012.739975

Villafañe V. E., Helbling E. W., \& Holm-Hansen, O. (1993). Phytoplankton around Elephant Island: distribution, biomass and composition. Polar Biology, 13, 183-191.

Villafañe, V. E., Helbling, E. W., Holm-Hansen, O., \& Montes. M. (1995). AMLR program: horizontal and vertical distribution of phytoplankton biomass near Elephant Island during January, February, and March 1995. Antarctic Journal of the U.S.,

30(5), 232-234 